\title{
Citizenship, Space and Democracy: Political Changes in the Context of Globalization
}

\author{
Gabriel Pérez Pérez \\ Department of Social Sciences, University Autonomy Metropolitan, Cuajimalpa, Mexico \\ Email: gpperez@correo.cua.uam.mx
}

How to cite this paper: Pérez, G. P. (2017). Citizenship, Space and Democracy: Political Changes in the Context of Globalization. Open Journal of Political Science, 7, 25-39.

http://dx.doi.org/10.4236/ojps.2017.71003

Received: October 24, 2016

Accepted: November 29, 2016

Published: December 2, 2016

Copyright $\odot 2017$ by author and Scientific Research Publishing Inc. This work is licensed under the Creative Commons Attribution International License (CC BY 4.0).

http://creativecommons.org/licenses/by/4.0/

\begin{abstract}
The article makes a theoretical reflection of space, which has been traditionally studied by geographers and citizenship, without making aside the empirical elements of this relationship. The first paragraph provides that studying the citizenship is necessarily linking it to the issue of democracy, and that, if there have been different approaches for spatial analysis at different scales, we have a diversity of forms and developments that have embraced democracy and citizenship. The second section is central to the theme of the city and it shows how they are given different manifestations and expressions of citizenship that responds to the transformation of public space and the fragmentation of the city. Finally, the third section deals with the theme on how their times currently can observe the emergence of new or different formations citizens. As a consequence of the global transformations, migratory transnational flows or social movements, citizens can be studied through different scales and spaces.
\end{abstract}

\section{Keywords}

Citizenship, Space, Democracy, City, Globalization

\section{Introduction}

The meaning of citizenship as belonging to a territorial National State has changed dramatically over the last years. The substance of national citizenships has been affected at different dimensions by the globalization process. As a result of the current changes, in the last two decades, there has been a renewed interest on the subject matter of citizenship and democracy.

In the nineteen nineties, several world regions underwent important political transformations; citizens in Eastern European States and South Africa started to exercise their rights, and transitions from military regimes in Latin America have favored the practice of democracy and citizenship. In societies such as those in Asia, there has been a renewed interest on the subject of liberal democracy, which has brought about some 
debates on the relevance of the very idea of citizenship. Moreover, in a world of higher economic, social and cultural interaction and migratory movements, the deepening and expanding of human rights, along with citizenship, seems more desirable than ever.

Facing this renewed interest in citizenship, human geography has sought to contribute to its analysis, from its own perspective, favoring ways of understanding political processes beyond the thinking tradition in which the meaning of democracy and citizenship were exclusively linked to the scale of the National State. The scholar concern of geography for the complexity of spatial relationships and scale, explains the strong affinity that this discipline has expressed towards theories which are critical of the universalizing vision of democracy and citizenship, provided that they do not attend to geographical variations in social, cultural and political formations.

This article is about the contribution done by geography and the interest that has awaken in some political and social scholars on the study and analysis of the subject of citizenship, through the use of space, place and scale as object of their analysis. In the first part, we establish that studying citizenship necessarily means linking it to the subject of democracy, and that if different approaches of spatial analysis are taken at different scales, we find ourselves in front of a diversity of forms and developments taken by both democracy and citizenship. The second part's central axis is the subject of the city and how various manifestations and expressions of citizenship responding to public space transformation and city fragmentation are found within it. Finally, we discuss how in current times the rise of new or different citizen formations, the result of global transformations, transnational migration flows or social movements can be observed, and the possibility for them to be studied trough different scales and spaces.

\section{Citizenship and Spaces of Democracy}

The study of citizenship had been carried out mainly by political scientists and sociologists, but geographers ${ }^{1}$ began to focus their attention on the issue of rights and citizenship towards the end of the nineteen eighties. Various special supplements, such as Environment and Planning A (1994) and Political Geography (1995) examined new areas of citizenship and the way spaces at different scales were used to make claims for rights and expand rights. An emphasis on location in terms of struggles against the restructuring and the expanding of rights has been noticeable in geographical contributions to the subject of citizenship.

This re-emergence of the interest in citizenship is due to several reasons. First of all, in the United States and Britain, the conservative governments of the 1980s implemented neoliberal programs that undermined the role of the State in the benefit of private provision, and encouraged a type of citizenship with more responsibilities. In second place, criticism towards old political participation models that were no longer perceived as effective, such as Unions. In third place, sexual and feminist movements demanded a more complete and rapid inclusion in society. As a consequence, the fourth element criticizes the historic construction of the public/private dichotomy, in

${ }^{1}$ Among the geographers and researchers who have specially emphasized the topic of citizenship, democracy and space are Barnett, Low, Marton, Mitchell, \& Jones (2004), Kofman (2003), Isin (2002), Rasmussen, \& Brown (2002) and Holston (2002). 
which the presence of women in public space became difficult. In fifth place, the age of global migration in which the position of migrants in between States has been subject of attention. Finally, a whole range of new rights, such as cultural, indigenous peoples, environmental and more recently new technologies rights and cyber-citizenship were being added to the political agenda (Kofman, 2003: pp. 393-394).

Nowadays, it is not possible to talk about citizenship without touching on the subject of democracy; these two dimensions of political analysis are intrinsically linked today. Therefore, democracy expansion or globalization is particularly important to citizenship. Democracy has become both a global value and a global transformation process. Moreover, globalization has separated democracy from its exclusive association with national citizenship and, in more diversified societies, discourses of global democracy rights have even mobilized new citizenship forms and forces, in a good proportion due to the fact that they raise the issue of social and economic inequities suffered by many and intensified by globalization of capital and labor hand.

According to Barnett and Low (2004: pp. 9-10) the democratic theory has had a persistent problem in tackling the meaning of its own implied geographical assumptions. This is related to the conceptualization of limits and borders, which becomes a key issue in determining the reach of the existing government and political identities. Geographical assumptions on delimited territorial entities have very often not been conceptualized in democratic theory, although there is also a strong positive argument about the fact that democracy is not possible without geographical limits between political entities. In accordance to this, there is a whole research agenda in human geography ${ }^{2}$, which can lead to potential connection points with democratic theory and citizenship that are currently being overlooked.

The subject of citizenship poses questions concerning the spaces in which democratic politics occur, and particularly about relationships between different spaces of democracy-between domestic spaces and national political entities, between the spaces of cities and wider regional and national scales, and between politics at a national level and international migration processes. The questions being studied by geographers, using their specialization in space, place and scale, are the subject of who exactly should participate, how this participation will be organized and which is the spectrum of actions within the democratic vision. This three dimensions - the who, how and what of democracy, are directly linked to the problem of citizenship. The geography of democracy is directly involved in determining practical solutions to these queries about the meaning of democracy and citizenship.

Assertions about the universality of democracy have been questioned from a spatial and geographical perspective. Authors such as O'Loughlin, Barnett and Low, state that

\footnotetext{
${ }^{2}$ Interdisciplinary research by geographers has been characterized by the presence of three dimensions: First, conceptualizations of space, place and scale done by geographers emphasize complexity and differentiation. Geographers' spaces are uneven, relational, reticular, blurry, stratified, superposed, porous, etc. In second place, the geographers' strong emphasis on constructed, non natural, qualities of territorial entities has led to caution in focusing on national scales of political action. There is an internal driving force to decentralize and denaturalize national scale as the privileged focus of attention. In third place, and in continuity with both of the preceding points, the preferred analysis scales in geographic research tend to place themselves both above and below the National State, with the local, urban, regional and transnational.
} 
the so called "third wave of democracy", established by Huntington, in the last three decades, is in fact the realization of a teleology towards representative liberal democracy. What these authors propose is that liberal democracy's universality is false, since it masks a number of particular exclusions.

It is a fact that the virtues of democracy are now practically universally accepted and that the increase of democratic States after the fall of the communist block is undisputable. What is being questioned is whether those new democracies are stable, whether they are truly democratic and not only autocratic governments disguised as democratic, and if there is a general global democratization process or recent developments are independent results of local circumstances not suitable of being generalized. In addition to this, something that is also questioned is the studies of democracy, carried out after the Cold War, in which rather than considering political advances as separate events, researchers started to look at them as part of a pattern, of the so called "Third Wave" of democratization. A model such as this, proposing a structural tendency, is seen by geographers and some comparative politics scholars with skepticism because of the lack of emphasis on regional and national differences of democracy (O'Loughlin, 2004: pp. 23-25).

The third wave of democracy has, in general, had a positive effect on citizen participation, which also presents regional differences, but it is a fact, in the case of the democratic transition in Latin America for instance, that there is higher freedom of speech, a more critical public opinion has developed and a whole range of bases for citizen participation have been established trough local NGOs that have transnational networks, which has activated a series of struggles for the defense of citizen rights and obligations (Roberts, 1995: pp. 184-207).

Nevertheless, the 'wave' has not continued its ascending trajectory either, but it has stabilized towards the beginning of the Twenty first century. Something particularly noticeable about the democratizing trend of the nineties is its macro-regional character, which clearly states it is a question of regional location. The "third wave" has had more expansion than depth, and outside the industrialized countries, liberal democracy tends to little institutionalization.

Democratization has moved in regular diffusion patterns in terms of space and time, but with different regional tendencies. Explanations at a regional level, rather than macro-structural ones, are needed to explain the political changes in latter times. Geographical disparities in global democratization tendencies had barely been mentioned in previous studies at a global level. Geographers, as well as some political scientists, have opted for an analytical model that examines both global tendencies and local circumstances in an interactive way. It can be stated that the meaning of democracy is, to a certain extent, specific of a place, and that without denying global tendencies, several clear differences are evident within the group of stable democratic countries (O'Loughlin, 2004: pp. 27-29).

${ }^{3}$ This democratization wave has dramatically reconfigured world political geography. The percentages of countries with democratic regimes are $89 \%$ in the Americas, $34 \%$ in Africa, $63 \%$ in the Asia-Pacific region and $70 \%$ in the region formerly controlled by the extinct Soviet Union. Only in the Middle East are democratic regimes a minority (Israel and Turkey), although debate over democracy is present in the region and there are several local democratization projects (Holston, 2002: pp. 325-332). 
At this moment, discourses about democracy, citizenship, and human rights, create a formative context almost omnipresent for the political action of States, corporations, social movements, or individual citizens. Democratization has, both historically and in the present period, followed multiple trajectories. Real political transition periods can be the result of contingent combinations of "top-down" international pressures for good governance and "bottom-up" pressures for social change and higher accountability. Criticism to the alleged universalism of democracy implies that the conceptualization of democracy, and not only the empirical research thereon, is an inherently geographical task (Barnett \& Low, 2004: pp. 12-14).

One of the theoretical approaches retaken by geographers, for the analysis of democracy, citizenship and space, is the theory of radical democracy, which is a term that gained acceptance through the work of Chantal Mouffe. This particular approach strives to revive the centrality of citizenship, minimized both by liberal theory and Marxism alike, by restricting political relationships to the domains of the State or economics. The goal of the radical democracy theory is to generate an anti-essentialist politics that continually attempts to redefine itself in order to resist the exclusion of individuals and groups in the formation of social order. This theory takes the mantel of democracy embracing the commitment to equality and participation, but it includes the radicalization of politics through a commitment to constant social change. The consequence has been a renewal of citizenship and its recognition of the complexity of political struggles of marginal groups (Rasmussen \& Brown, 2002: pp. 175-188).

For Chantal Mouffe (1999: pp. 89-106), it is necessary to establish a concept of democratic citizenship that recognizes the fundamental role of the political community and opens a space to pluralism and multiplicity of alternative communities in which individuals participate. Therefore, it is paramount to restore politics, outside national and party like frameworks, recognizing that no space is immune to politicization. The task for pluralist modern politics is to try and find institutions, practices or discourses that achieve a transformation of the antagonisms, through mechanisms or instruments that allow the formation of order and consensus within a conflict situation.

Mouffe's assertions about "new spaces for politics" have been retaken particularly by geographers, in an attempt to understand how the "locality" of these new forms of citizenship mattered on the constitution, efficacy and failures. Thus, the thesis is that radical democratic theory could help understanding new forms-and places-of political action and responses. Therefore, radical democracy is positioned in terms of its theoretical underpinnings and through empirical practices.

Radical democratic theory identifies that all political struggles are temporary and contextual, contingent to power relationships that become antagonistic in particular moments and places. Radical democracy allowed the recognition that the territory or space of politics is not predetermined and therefore, the theorization of a political changing object needed to recognize the way in which radical democratic action emerged in actual conflicts. Citizenship could not be understood as an abstract object of specific characteristics or principles, but it was a concept continually reformulated through actual political participation within a context.

By redefining interpretations of politics, citizenship is recognized as a practice relating 
political identities, everyday life practices and political communities. Citizenship understood as a struggle to define the space of the political, expands the theoretical and empirical possibilities for democracy. The multiple locations of citizenship have also fostered a wider discussion as to how citizenship can operate at various levels, ranging from local to global (Rasmussen \& Brown, 2002: pp. 175-188).

\section{City and Citizenship: The Transformations of Public Space}

In western imagination it is impossible to separate the city, democracy and citizenship. A continuous unit of history, like a seamless net where city, democracy and citizenship are linked to one another, has been built. But if we look at social movements and claims for citizen rights that emerge in cities, these images are more incongruous every time, with the contemporary practices that constitute themselves as political, and given that constitution, different images of city, democracy and citizenship start to be produced (Isin, 2002: pp. 305-316).

Authors such as Jones (2004) and Holston (2002) have pointed out that cities are becoming the space of citizenship, because of the emerging forms of action and participation being developed. Cities become public spaces ${ }^{4}$ not in a topographic or institutional sense, but in the fact that they become "sites" of power, of common action coordinated through speech and persuasion. The redefinitions of citizenship achieved through struggle for inclusion, have reinforced, and even transformed, normative ideals incorporated in notions of public space. By vindicating the rhetoric of inclusion and interaction that the public space must represent, excluded groups have managed to argue in favor of their rights as part of the active public.

Cities, and especially metropolitan regions, would be the crucial sites for the impact of global democracy ${ }^{5}$ and the strategic arenas for the development of new citizenships, given the fact that they allow that consequences of global capitalism and migration are experienced by masses of people. These people mobilize around right claims related to concerns derived from such consequences and become active citizens who develop new sources of law and new citizenship agendas. Thus, life experience becomes the context and substance of new emerging forms of citizenships (Holston, 2002: pp. 325-332).

The generation of new urban citizenships is one of the important consequences of the globalization of democracy in city-regions. It is possible to speak about urban citizenship when the city is the most important political community, when residence in the city is the criterion for belonging as well as the basis for political mobilization, and when rights claim, related to the urban experience and civic activity, are constitutive of

${ }^{4}$ Public space works as the physical place where social interactions and public activities of all members of society occur. Public space becomes a basis on which, and from which, political activity flows. It is in the context of public spaces where alternative movements can emerge and fight on citizenship and democracy issues (Mitchell, 2003: pp. 130-134).

${ }^{5}$ Global democracy is the democratic law which must be enshrined not only within the domains of power integrating particular political communities, but also among interaction networks which cross territorial borders. Power networks may be national, transnational and international. Therefore, democratic public law within a political community needs democratic law in the international sphere. Public democratic law must be sustained and supported by an international legal structure enshrined both within borders as well as through borders (Held, 1997: pp. 271-276). 
citizenship. As Isin (1996: pp. 21-36) points out, the global city region ${ }^{6}$ is a specific kind of territory where new citizenship practices have been developed and invented, as well as concrete, fluent and decentralized movements focused on local and specific matters, such as the destitute citizens who are uniting to create new forms of housing themselves.

Citizenship is facing a process of spatial fragmentation occurring in cities. In Buenos Aires, Caracas and Santiago, decentralization initiatives have been used to decentralize elite areas from municipal government, to impose restrictions to street vendors and to avoid that taxes on property are used to subvention investments in poorer areas of the city. Real estate companies have promoted environmental discourses in order to rezone areas for the benefit of better off social groups. Many of the biggest developments include shopping centers, schools and hospitals within their walls, and new facilities such as art museums and private universities in nearby locations. In "selling" places, real estate developers seize people's concerns regarding security by emphasizing physical isolation and separation of the new developments; characterizing spatial distance as a symbol of social distinction. As a consequence of all this, the spaces for heterogeneous and spontaneous contact decrease (Jones, 2004: pp. 168-171).

According to García Canclini (1995), these tendencies set a change in urban aspirations in Latin America, where exclusion is reinforced with the creation of "public spaces" in which people are physically close but disperse in every other way, except through a private ethos of consumption. He argues that citizenship is experienced in spaces that have lost their normative focus in such a way that it is no longer possible to imagine the construction of a modern urbanism similar to that of Paris, New York or even Miami, but only "disintegrated" cities that have become "Hollywood's suburbs".

In Puebla, México, the new shopping centers located within the city are accessible by car only. They are designed as closed spaces with a defensive architecture, with only half a dozen entrance gates, with climate control, and very few public telephones or seats, and it is very rare to see indigenous people in there. Their "public spaces" include amusements such as an ice skating rim and spaces for the exhibition of imported cars. Shopping centers offer a natural runway for youth, where they can be consumers and spectators. In contrast, in the Shopping Center called Angelópolisa single bookstore cannot be found. In Puebla, the city center recovery project, through its preservation and transformation into "historic center", emphasizes an elite representation space, with a European style, more order, cleanliness, moral and dignified use. Some people

\footnotetext{
${ }^{6}$ The concept of "global city regions" shows how city regions increasingly work as essential spatial nods of global economy and as singular political actors in the world scene. City-regions are becoming more central in modern life's configuration, and even more as globalization (in combination with the waves of technological change) has reactivated their importance as a basis for all possible forms of productive activity, whether it is manufacturing or services, advanced technology or simple technology sectors (Scott, Agnew, Soja, \& Storper, 2002: pp. 11-32).

${ }^{7}$ For García Canclini (1995: pp. 29-30), the changes in the building style have altered citizen possibilities and forms of being. Along with the transformations of politics and the decrease of institutions, other ways to participate are gaining strength. The population perceives that many of the questions citizens have where do I belong and what rights does that give me? How can I inform myself? Who represents my interests? Are answered more by the private consumption of goods and mass media than by the abstract rules of democracy or by collective participation in public spaces.
} 
from the elite and middle classes plead for the removal of the poor, the noisy, the indigenous, the vendors, the youth, who exhibit the differences from "civilized" standards in the way they eat, play music, curse, or simply their handicap for consumption (Jones, 2004: pp. 168-171).

The new public spaces in the city centers of Puebla, Quito, Cartagena, Mexico City or Rio de Janeiro are art museums and convention centers, European style coffee shops, or antique landscape recreations. Similar examples can be seen in downtown Bogota or Buenos Aires, where the public nature of a policy emphasizing an increasingly private ethos is trying to be transmitted. With the arguable exception of Brazil, democratization in Latin America has not been accompanied by a debate regarding what kind of vision of urban space is compatible with more inclusive notions of citizenship.

Spaces become public when they inform others about the discourses of the groups who physically occupy them or symbolically provide them with significance. Therefore, it is in the public space that identities are exposed and communicated, interpreted, understood and transformed. Space representations become strategic sites for the struggles of citizenship and democracy. Citizenship does not have a defined meaning and cannot be thought as a concession by the State, but it is actively and constantly built through identification with a variety of groups or systems of values which are not based on limited or predetermined identities.

Regarding space representations as strategic sites for the dispute of citizenship, Jones (2004: pp. 176-180) highlights the example of a network of social movements formed explicitly to oppose the privatization of public space both in a physical and a discursive way. The case starts with the announcement by the Mexican federal government in 1993, for a mega urban project in the city of Puebla set out as vital to trigger economic growth in the city. The project affected directly four districts, or barrios, of the city center, in their orientation, architecture, socioeconomic basis and possibly their ethnic composition. The project presented the barrios as incompatible with the reconstruction of Puebla as a modern city, and they seemed to be even more out of place after the redefinition of public space in the historic center.

The project sparked off a series of movements that eventually gave birth to the Union of Free Citizens (UCL, its acronym in Spanish), a movement that sheltered several groups opposing the complete package for Puebla's privatization, which included peasants, low income settlement duelers, parents organizations, among others. The UCL did not manage to stop project implementation, though it was modified.

It is worth noting that these movements challenged the discourses of an imagined cultural identity, that presented the barrios as "traditional", "local" and "popular" in the sense of being anti modern. The UCL projected their identities through multiple spatial dimensions of the barrios, encouraging a series of debates that reached the media and other areas. For instance, they challenged the official idea of barrio identities as fixed in the space and subject to dissemination in order to preserve some aspects compatible with the project and dispose of others. The UCL argued that the barrios were social and cultural spaces in which identities were related to particular popular practices that were not only reduced to concrete sites, such as the Saints celebrations, the preparation of foods, etc., which appealed to the idea of the Mexican and Poblana identity. 
Defenders of the barrios described the Project as invasive and the inhabitants of these districts as part of the resistance towards the privatizing interests of the NAFTA. They highlighted the idea of the barrios as not "made in USA", in contrast to the Angelópolis project which attempted to turn the city into a Disneyland or a small Las Vegas or Texas City. Thus, far from accepting the representation of the barrio as not modern, the UCL gave that adjective to the project itself because of its lack of originality, and described it as an excess of capitalist modernity. Their strategy was to project identities and visions of the barrio that were compatible with a progressive modernity. Apart from presenting the barrios as democratic spaces where rights were respected, given the fact that civil associations were open and not hierarchical, and emphasized the participative nature of their organization.

In Jones' example, there is an evidence of citizen participation, which is in harmony with the spatial dimension of politics. If we understand that social practice is discursive and the meaning of social action is changing and being constantly refuted, then space becomes important to understand these processes. If the city is analyzed, it is worth noting that this space is increasingly fragmented. This means that relations of power are much more untidy. How people relate to the space and give significance to it, becomes a fundamental power exercise, in which the struggle for the representation of space makes political identities public.

Since the nineteen sixties, the development of cities, the expansion of social movements, the right to inhabit the city and to define the use of public spaces became more significant as marginal populations were expelled towards the periphery. During the eighties, the struggles for the constructed environment intensified under neoliberalism and the effects of economic restructuring, while fortified and patrolled spaces were built by privileged private agents. Those who are denied legal status can, nevertheless, participate in political activism and influence local politics, just like in the case of undocumented Latin American workers in Los Angeles, California. By using a wide range of protest strategies in different spaces (walks, demonstrations, squatting theaters and churches, hunger strikes) undocumented workers have succeeded in forming alliances, and reaching a reconsideration of their status. Inclusion may, however, be more effective through actions taken at the neighborhood and community levels (Kofman, 2003: pp. 397-398).

\section{Globalization, Space and Citizen Formations}

The emphasis in the formation of citizenship allows us to think of it as something in constant change and not a final product. Nevertheless, its primary definitions generally derive from the State. There is a great geographical variety in the forms in which different States define and manipulate the concept of citizenship. This variety is also expressed in changes within the definitions of State over time, specially as different groups claim their "rights" as citizens, or even to be considered as such. The idea of formation emphasizes the dynamic and non-linear quality of citizenship, which can expand or contract at different moments depending on the context in which the State is integrated to global economy, the types of internal battles occurring within the States' boundaries, or other variables. Thus, in contrast with the image of citizenship as ever 
expanding and with an ever more inclusive framework, as it has been stipulated by Marshall ${ }^{8}$, the idea of citizenship formation emphasizes its elastic qualities, that can in fact expand, but also contract or change form completely.

One of the central forces affecting citizenship formation is the economy. The State's position regarding capital is absolutely crucial to understand how and why citizenship is defined or redefined the way it is. That is so for local government, urban development and citizenship practices at the neighborhood or city level alike. The national scale is not the key to understanding negotiations regarding economic and political power and the meaning and practice of citizenship. Political and economic restructuring seems to consistently enable new scales for political action, and in this process, it allows a definition of rights and duties for national citizenship. Studies on citizenship, carried out from a human geography perspective, seek to incorporate other forms of social division apart from class, such as "race" or gender, or other global phenomena like migration. The times of "new post fordism"9 meant new scales of space organization other than the National State had to be taken into account to understand the uneven access to rights.

For Marston and Mitchell (2004: pp. 95-100), some of the most important contemporary criticisms to the concept of citizenship have come from feminist theories that have pointed out the practical and political problems regarding gender, that are inherent to the liberal formulation of a universal and neutral citizen. In western democracies, the concept of citizen has been linked to relations of property in the market, and in its more liberal aspect, it has been a political, social and legal status to which a whole series of individuals have been denied access, on the grounds of their ethnic group of origin or their socioeconomic condition. There is an enormous gap between the liberal ideal and the real exclusion of citizenship in the real practice, women and other groups have been excluded from participation in civil society by cultural schemes that believed that their 'disordered' nature prevented them from rational thinking and the development of a sense of justice. Thus, the ideas regarding natural roles for men and women have been and still are central to the ideological justifications of the national community of citizens and their relation to the State. By pointing out the main failures of the liberal construction of citizenship, feminists have shown how cultural interpretations of natural roles for men and women have had a direct impact on those failures.

${ }^{8}$ T.H. Marshall, claimed that citizenship brought about equal rights, at least formally, to individuals in a group of spheres in constant expansion (civic, political and social) and granted access to a growing number of the oppressed and marginalized (workers, women, racial minorities). Apart from the fact that citizenship requires a community based on the loyalty to a common civilization. Marshall falls prey to the ideological promise of liberalism and fails to see the inherent inequality of capitalism, on top of the fact that his postulates posses colonial, Eurocentric and racist connotations of "civilization" which dichotomized the world into those who were civilized and other barbarians who were described as inadequate for citizenship (Stasiulis \& Bakan, 2005: pp. 11-18).

${ }^{9}$ The Fordist regulation model corresponds to the time in which national economies were built after 1945 . Economic institutions were based on political institutions on which they depended, all of them in harmony with Keynesian welfare State, which in time developed a given type of citizenship. Economic globalization and the crisis of the fordist model have opened national economies previously closed in their borders, making these spaces more permeable to the effects of international and transnational forces. Facing the economic restructuring of present times, some authors have set forth the need to research the effects of these changes on citizenship and try and decipher whether new rights speaking of a kind of postfordist citizenship can be generated (Jenson, 1996: pp. 13-20). 
From the sixties decade, a great number of groups have become more visible and have made their rights valid within a framework recognizing equity through difference. In some cases, such as in the case of the gay community, they have had to struggle against criminalization before they can demand egalitarian treatment in economic and social life areas, and their inclusion in State institutions, especially those maintaining order such as the police or the armed forces. Since Labors' government arrived to power in 1997, in the United Kingdom, the gay community has been gaining more recognition. In October 2000, the right for gay and lesbian individuals to remain as members of the armed forces was won. New spaces of citizenship have been formed, in those places less regulated by the State, and that operate with the help of volunteers. Civil rights have also been extended through the use of international human rights ${ }^{10}$.

On the other hand, the economic flows through borders, characteristic of globalization, people flows through national borders, have put a great deal of pressure both on politics and the conceptions of citizenship. In the last four decades, massive migration has had an intensity and range never seen before, causing the creation of multiethnic societies around the world, and also an increasing demand for the recognition and resistance of citizen rights and duties. In recent years, an important phenomenon called "transnational migration" has been developing itself; this is a new model, a pattern of migration in which migrants live a dual nationality, establishing homes and work places in more than one Nation State.

Transnational migration has enormous implications on the concept and practice of citizenship, giving place to a new way of thinking about national identity and national belonging, among migrants themselves. For instance, for some poor States, such as Mexico, The Dominican Republic and India, monetary remittances sent back "home" by migrants have become an indispensable part of their economy as recipient countries. Before risking losing loyalty from those migrants, many of whom have established jobs and residence in cities in more important countries, poorer States offer benefits such as "dual citizenship", which on top of conferring a constant sense of national identity and commitment, can also offer important material benefits, such as the right to inherit property.

What scholars like Martin (2000: pp. 25-31) are concerned about, is to what extent dual citizenship is a product of instrumental or selfish reasons, more that an expression of real commitment. To what extent can this dual citizenship lack cohesion, unity, membership, identification to the nation, loyalty, sacrifice, etc. This may mean serious problems, first of all degradation before the rest of the population of the meaning of citizenship, beyond a mere convenience alliance, and second, a lack of coherence of the citizenship institution, which significantly contributes to the glue that helps poly-ethnic societies find some measure of unit.

Dual citizenship is only an example of the many forms being proposed or implemented as a result of new tensions characteristic of global restructuring. The State, in a

\footnotetext{
${ }^{10}$ Marriage between same sex couples has been allowed since April 2001 in the Netherlands, August 2001 in Germany as well as heritage, pension and other rights in line with heterosexual couples. The registration of a Domestic Couple exists in the Nordic States as well as in France. The attempt to redraw the spaces of sexual citizenship and the distinction between the public and the private has been carried out through forms of activities of sexual dissidence, such as activism against AIDS (Kofman, 2003: pp. 397-398).
} 
certain way, has deterritorialized, in such a way that its foundation on a national community no longer corresponds directly with its territorial boundaries, and economic, political and governmental activities have reterritorialized to a regional an international level (Keating, 1997: pp. 383-398). Dual citizenship confers identity within a national community without the need to live or work in it, and with the legal agreement, national identity can be shared with another nation.

In relation to this, an example of citizenship formations highlighted by Marston and Mitchell (2004: pp. 106-110), is the case of thousands of people in the eighties and nineties, who left Hong Kong to go to Canada mainly because of the pending transfer of control from Great Britain to the People's Republic of China in 1997. In Canada, apart from the immigration process based on a score system, a special business immigration program was added in the eighties, which allowed wealthy investors and entrepreneurs to receive visas and enter the country with ease. The business immigration program, established in 1978, but widely expanded in 1984 and 1986, was explicitly designed to attract those who could contribute to Canada's economic development. By 1991, it was required for investors in this program to have a net personal value of at least five hundred thousand Canadian dollars, and promised to invest three hundred and fifty thousand on a Canadian investment project. It was expected from entrepreneurs to have a certain business record and to start a business venture in Canada employing at least one Canadian citizen. After three years of residence, immigrants could apply for Canadian citizenship ${ }^{11}$.

The arrival of the Chinese and the transformation of the space provoked thereof, by building huge houses in the neighborhood for example, caused tense discussions among society about immigration, citizenship and what it meant to be Canadian. For the first time, many Canadian residents questioned state policies on the issue of citizenship, something that had been taken for granted up to that point. For the first time, the legitimacy of the State to define immigration policy and citizenship was interrogated and questioned.

The very introduction of the "business" category to immigration reduced the State's legitimacy as an autonomous entity. Through the "selling of passports" to the highest bidder, citizenship became, both in an implicit and explicit way, a commercial matter, more that a political status. A set of selective rights were given, offered to wealthy citizen prospects; a situation which does not have democratic or egalitarian characteristic for the access to citizenship, but merely economic characteristics. The protection of citizenship in terms of its rights and duties became increasingly uneven, selective and fragmented. In a way, it seems to be a return to a kind of citizenship for those who possess property, in the way of the old city-state of Greece, where citizenship was limited to the privileged classes (Riesenberg, 1992).

In the modern history of citizenship formation in the West, it was established that

\footnotetext{
${ }^{11}$ For many years, Hong Kong was the main source of business immigrants to Canada. In Vancouver, the number of people who arrived from Hong Kong averaged 10,000 for the years between 1990 and 1996. Approximately one quarter of them arrived on the business program. The capital they brought to this region is estimated above a billion Canadian dollars a year, in the same period. This group rapidly became very prominent, and in many cases, their arrival also caused a great conflict in several economic, social and cultural arenas.
} 
the existence of the community of citizens was located within the national borders. As rights were established for citizenship historically, this sense of national community prevailed restricted to a territory by the National State (Schnapper, 2001: pp. 93-94). Nevertheless, with the arrival of new transnational actors such as the Hong Kong immigrants, this normative spatial connection between National State and citizenship presents a series of contradictions, rights and duties of Canadian citizenship are no longer tightly linked to the idea of a community limited by state borders. The case of the Chinese immigrants describes how a citizenship formation has moved from a sense of local community to a transnational sense.

The emergence of transnational social and political communities constituted by transborder migration, begins to work as a basis for new forms of citizen identity, to the point that community members manage to keep identification and solidarities one to another through territorial divisions of States. Thus, these are citizen identities emerged from networks, economic, political and cultural activities covering both origin and guest societies (Sassen, 2002: pp. 277-291). Contemporary transnational migration poses an important challenge to the modern conceptions of citizenship, as it generates complex and multidimensional relations between individuals, National States, labor markets, communities and homes.

\section{Conclusion}

Geographers' contribution to citizenship and democracy studies has been their specialization to study space, scale, territory, boundaries, etc., which has favored the interest of political theorists in the utilization of these analytical dimensions. These types of studies have contributed to higher theorization and research on the reconfiguration of the geography of democracy and citizenship.

The traditional political theory vision of geographical dimensions, taken as fixed and given dimensions, in the citizenship and democracy phenomena, or their concern for relatively simple concepts of scale and geographically contained policies, is derived from universalizing conceptions of citizenship rights and democracy. This vision can be transformed by the affirmation of the difference and diversity of the false universalism. This inversion can fit together with the already deeply established preference of geography for the value of the particular and the specific.

The debate on the process of reconfiguration of the political map is still active and the nature of democracy applied in different space contexts of States, regions and localities, is yet to be researched. Citizenship, in spite of a formal democracy that increasingly seems to make it present, is facing a set of new uncertainties: uncertainties having to do with migrant populations' inclusion and exclusion forms; uncertainty as to the location of sovereign power; uncertainties about the priorities of the National State; or uncertainty about the reconfiguration of cultural identities.

Citizenship is a concept in constant construction, particularly in periods of structural transformation at a great scale. An understanding of how those changes have occurred and how far they can go is even more important, especially the transformations that allow higher equality and justice for diverse and dynamic populations. Geographical scale is mainly implicated in contributing to the understanding of citizenship formations. 
What scales are important for the production of a given type of citizenship, depends on particular characteristics of different historical-geographical moments. The social-spatial organization deeply affects and is affected by the discourse and practices of citizenship formations.

An important contribution of geography to the problems of citizenship has focused on the different scales in which citizenship is practiced, and the use of different kinds of spaces, such as the public and the private, especially with relation to gender and sexual citizenship. Some geographers have considered the importance of scale for political and social action and organization. Geographers have tended to emphasize the need to study citizenship, empowerment and resistance at the local scale and in cities. They have also examined the ways in which social movements can move along scales and the importance of making specific claims in particular places.

Citizenship has called a great deal of attention in recent years because of the widely spread economic, social, cultural and political changes that have taken place at different scales, and the emergence of new claims for individual and group rights. Today's challenge is to promote equality through a reference framework recognizing different ways of membership and belonging. Particularly, that requires a rethinking of spaces in which individuals and groups can be incorporated as citizens without being confined to national spaces and the rigid public/private division. Geographers have called attention to the complexities and ambiguities of the practice of citizenship at different scales and in different spaces.

\section{References}

Barnett, C., \& Low, M. (2004). Geography and Democracy: An Introduction. In: C. Barnett, \& M. Low (Eds.), Spaces of Democracy. Geographical Perspectives on Citizenship, Participation and Representation (pp. 1-22). London: Sage Publications. https://doi.org/10.4135/9781446216309.n1

García Canclini, N. (1995). Consumers and Citizens. Globalization of Multicultural Conflict. México: Grijalbo.

Held, D. (1997). Democracy and the Global Order. From the Modern State to Cosmopolitian Governance. Barcelona: Paidós.

Holston, J. (2002). Urban Citizenship and Globalization. In: A. J. Scott (Ed.). Global CityRegions, Trends, Theory, Policy (pp. 325-348). Oxford: Oxford University Press.

Isin, E. F. (1996). Global City-Regions and Citizenship. In: R. Keil, G. R. Wekerle, \& D. V. Bell (Eds.), Local Places in the Age of the Global City (pp. 21-34). Montréal: Black Rose Books.

Isin, E. F. (2002). City, Democracy and Citizenship: Historical Images, Contemporary Practices. In: E. F. Isin, \& B. S. Turner (Eds.), Handbook of Citizenship Studies (pp. 305-316). London: Sage. https://doi.org/10.4135/9781848608276.n19

Jenson, J. (1996). Post-Fordist Citizenship: Struggling to be Born. In: R. Keil, G. R. Wekerle, \& D. V. Bell (Eds.), Local Places in the Age of the Global City (pp. 13-20). Montréal: Black Rose Books.

Jones, G. A. (2004). The Geopolitics of Democracy and Citizenship in Latin America. In: C. Barnett, \& M. Low (Eds.), Spaces of Democracy. Geographical Perspectives on Citizenship, Participation and Representation (pp. 161-184). London: Sage Publications. https://doi.org/10.4135/9781446216309.n9

Keating, M. (1997). The Invention of Regions: Political Restructuring and Territorial Govern- 
ment in Western Europe. Environment and Planning C: Government and Policy, 15, 383-398. https://doi.org/10.1068/c150383

Kofman, E. (2003). Rights and Citizenship. In: J. Agnew, K. Mitchell, \& G. Toal (Eds.), A Companion to Political Geography (pp. 393-407). Oxford: Blackwell Publishing. https://doi.org/10.1002/9780470998946.ch25

Marston, S. A., \& Mitchell, K. (2004). Citizens and the State: Citizenship Formations in Space and Time. In: C. Barnett, \& M. Low (Eds.), Spaces of Democracy. Geographical Perspectives on Citizenship, Participation and Representation (pp. 93-112). London: Sage Publications. https://doi.org/10.4135/9781446216309.n5

Martin, D. A. (2000). Introduction. Part One: Citizenship in Countries of Immigration. In: T. A. Aleinikoff, \& D. Klusmeyer (Eds.), From Migrants to Citizens. Membership in a Changing Word (pp. 25-31). Washington, DC: Carnegie Endowment for International Peace.

Mitchell, D. (2003). The Right to the City. Social Justice and The Fight for Public Space. New York: The Guilford Press.

Mouffe, Ch. (1999). The Return of the Political. Community, Citizenship, Pluralism, Radical democracy. Barcelona: Paidós.

O'Loughlin, J. (2004). Global Democratization: Measuring and Explaining the Diffusion of Democracy. In: C. Barnett, \& M. Low (Eds.), Spaces of Democracy. Geographical Perspectives on Citizenship, Participation and Representation (pp. 23-44). London: Sage Publications. https://doi.org/10.4135/9781446216309.n2

Rasmussen, C., \& Brown, M. (2002). Radical Democratic, Citizenship: Amidst Political Theory and Geography. In: E. F. Isin, \& B. S. Turner (Eds.), Handbook of Citizenship Studies (pp. 175188). London: Sage. https://doi.org/10.4135/9781848608276.n11

Riesenberg, P. (1992). Citizenship in the Western Tradition. Plato to Rousseau. Chapel Hill, NC: The University of North Carolina Press.

Roberts, B. R. (1995). The Making of Citizens. Cities of Peasants Revisited. London: Arnold.

Sassen, S. (2002). Towards Post-National and Denationalized Citizenship. In: E. F. Isin, \& B. S. Turner (Eds.), Handbook of Citizenship Studies (pp. 277-291). London: Sage. https://doi.org/10.4135/9781848608276.n17

Schnapper, D. (2001). The Community of Citizens. About the Idea Modern of Nation. Madrid: Alianza.

Scott, A. J., Agnew, J., Soja, E. W., \& Storper, M. (2002). Global City Regions. In: A. J. Scott (Ed.), Global City-Regions, Trends, Theory, Policy (pp. 11-32). Oxford: Oxford University Press.

Stasiulis, D. K., \& Bakan, A. B. (2005). Negotiating Citizenship. Migrant Women in Canada and the Global System. Toronto: University of Toronto Press. 
Submit or recommend next manuscript to SCIRP and we will provide best service for you:

Accepting pre-submission inquiries through Email, Facebook, LinkedIn, Twitter, etc. A wide selection of journals (inclusive of 9 subjects, more than 200 journals) Providing 24-hour high-quality service

User-friendly online submission system

Fair and swift peer-review system

Efficient typesetting and proofreading procedure

Display of the result of downloads and visits, as well as the number of cited articles Maximum dissemination of your research work

Submit your manuscript at: http://papersubmission.scirp.org/

Or contact ojps@scirp.org 